\title{
ANALISIS KANDUNGAN MERKURI DAN SIANIDA DI DAERAH ALIRAN SUNGAI TALAWAAN, SULAWESI UTARA
}

\author{
Sitti N. Sultan ${ }^{1)}$, Jemmy Abidjulu' ${ }^{1)}$, Harry S. J. Koleangan ${ }^{1)}$ \\ 1)Jurusan Kimia, FMIPA, Universitas Sam Ratulangi, Manado \\ e-mail: ssnasriah@yahoo.com; jemmyabidjulu@yahoo.com; harrykoleangan@yahoo.com
}

\begin{abstract}
ABSTRAK
Telah dilakukan penelitian untuk menentukan konsentrasi merkuri dan sianida di DAS Talawaan dengan metode Spektofotometer Serapan Atom Uap Dingin (CVAAS) untuk merkuri dan Spektrofotometer HACH DR 5000 untuk sianida yang kemudian dibandingkan dengan hasil penelitian sebelumnya. Pengambilan dan pengujian sampel dilakukan sebanyak dua kali dengan selisih waktu 1 bulan. Hasil penelitian menunjukkan bahwa konsentrasi merkuri dibawah batas deteksi yaitu $\leq 0,0007 \mathrm{ppm}$ yang dalam penelitian sebelumnya berkisar pada 0,0013-0,0015 ppm. Sedangkan konsentrasi sianida di DAS Talawaan berkisar pada 0,001-0,01 ppm, tidak jauh berbeda dengan penelitian sebelumnya yaitu berkisar pada 0,005-0,017 ppm.
\end{abstract}

Kata kunci: pencemaran, merkuri, sianida, DAS Talawaan

\section{CONTENT ANALYSIS OF MERCURY AND CYANIDE IN TALAWAAN WATERSHED, NORTH SULAWESI}

\begin{abstract}
Has conducted a study to determine the concentrations of mercury and cyanide in the Talawaan watershed with methods Cold Vapor Atomic Absorption Spectrophotometer (CVAAS) for mercury and HACH DR 5000 Spectrophotometer for cyanide which is then compared with the results of previous studies. Making and testing of samples performed twice with a gap of 1 month. The results showed that mercury concentrations below the detection limit is $\leq 0,0007 \mathrm{ppm}$ in previous research revolves around 0,0013-0,0015 ppm. not much different from previous studies that range in 0,005$0,017 \mathrm{ppm}$.
\end{abstract}

Keywords: pollution, mercury, cyanide, DAS Talawaan

\section{PENDAHULUAN}

Indonesia merupakan negara yang kaya akan sumber daya alamnya. Baik itu flora, fauna dan berbagai hasil bumi yang sangat bermanfaat bagi manusia. Salah satu potensi sumber daya alam tersebut adalah emas yang digunakan sebagai standar keuangan di banyak negara dan digunakan juga sebagai perhiasan (Inswiarsi dan Martono, 2007). Karena kegunaannya ini, semakin banyak penambang yang berburu mendapatkan sumber daya alam ini, diantaranya yaitu para penambang emas rakyat.

Pada aktivitas tambang emas rakyat selalu menggunakan merkuri pada proses penambangannya. Akibatnya merkuri mencemari lingkungan, yaitu sebagian besar terlepas ke udara dan sebagian kecil ke dalam air (Palapa, 2012). Di tambang emas rakyat Tatelu Sulawesi Utara, para penambang biasanya menggunakan merkuri sebanyak 4 ons untuk mendapatkan emas sebanyak 2 gram.

Walaupun pada konsentrasi yang sangat rendah, logam merkuri dapat berpengaruh langsung dan dapat terakumulasi pada lingkungan sehingga dapat berdampak pada kesehatan manusia. Menurut Lestarisa (2010), seperti halnya sumber pencemar lingkungan lainnya, logam berat dapat ditransfer dalam jangkauan yang sangat jauh di lingkungan, sehingga berpotensi mengganggu kehidupan biota lingkungan dan berpengaruh pada kesehatan manusia. 
Menurut Polii dan Sonya (2002), kandungan merkuri dan sianida yang melebihi Baku Mutu Lingkungan dapat mengakibatkan kerugian. Merkuri di perairan dapat terkonsumsi oleh ikan, ganggang, dan tumbuhan air. Hal ini sangat berbahaya jika ikan yang terkontaminasi merkuri dikonsumsi manusia. Selain itu penggunaan air sungai yang terkontaminasi merkuri dan sianida juga dapat berdampak buruk bagi manusia, diantaranya kerusakan otak, cacat, hingga pada kematian.

Sebelumnya, telah ada yang meneliti kandungan merkuri dan sianida di Daerah Aliran Sungai Talawaan. Berdasarkan penelitian yang telah dilakukan oleh Masloman (2005), kandungan merkuri di DAS Talawaan pada cuaca hujan berkisar 0,0008 $0,032 \mathrm{ppm}$ dan pada cuaca cerah berkisar 0,004-0,112 ppm, serta kandungan sianida pada cuaca hujan berkisar 0,007-0,016 ppm dan pada cuaca cerah berkisar 0,018-0,069 ppm. Selain itu, penelitian lainnya yaitu Komalig (2006), kandungan merkuri di sungai Talawaan berkisar 0,0013-0,0015 ppm dan sianida berkisar 0,005-0,017 ppm. Karena adanya perubahan dan perkembangan para penambang dalam menggunakan merkuri menjadi sianida serta mulai berkurangnya aktifitas penambangan di kawasan tambang emas rakyat di Daerah Aliran Sungai (DAS) Talawaan maka dilakukan penelitian untuk mengetahui kandungan merkuri dan sianida di beberapa titik di DAS Talawaan untuk dibandingkan dengan penelitian sebelumnya

\section{BAHAN DAN METODE Bahan dan Alat}

Alat yang digunakan adalah botol gelas berwarna gelap, indikator $\mathrm{pH}$, cool box, hot plate, seperangkat Spektrofotometer HACH DR 5000, seperangkat CV-AAS (Cold Vapour Atomic Absorpsion Spectrometry), alat-alat gelas seperti gelas piala, gelas ukur, labu ukur, erlenmeyer, pipet.

Bahan yang digunakan sampel air, asam nitrat $\left(\mathrm{HNO}_{3}\right)$ pekat, merkuri klorida $\left(\mathrm{HgCl}_{2}\right)$ anhidrat, natrium hidroksida $(\mathrm{NaOH})$, $\mathrm{H}_{2} \mathrm{SO}_{4}$, asam klorida $(\mathrm{HCl})$, timah klorida $\left(\mathrm{SnCl}_{2}\right)$, kalium permanganat $\left(\mathrm{KMnO}_{4}\right)$, kalium persulfat $\left(\mathrm{K}_{2} \mathrm{~S}_{2} \mathrm{O}_{8}\right)$, natrium hidroksilamin klorida $\left(\mathrm{NH}_{2} \mathrm{OH}\right)_{2} \mathrm{NaCl}$, aquades, pillow reagen cyaniver 3 , pillow reagen cyaniver 4 , pillow reagen cyaniver 5 .

\section{Pengambilan Sampel}

Air diambil dari 4 titik yaitu dari desa Wasian, Talawaan, Patokaan dan di muara DAS Talawaan. Pengambilan sampel dilakukan sebanyak 2 kali diwaktu yang berbeda, yaitu pengambilan sampel kedua (saat hujan) dilakukan 1 bulan setelah pengambilan sampel pertama (saat cerah).

Teknik pengambilan sampel untuk pengujian merkuri dilakukan dengan menggunakan metode Integrated Composite dalam Suheryanto et al. (2013). Sampel air diambil dari lapisan atas (sekitar $10 \mathrm{~cm}$ dari permukaan) air sungai dimasukkan kedalam botol gelas lalu ditambahkan $\mathrm{HNO}_{3}$ hingga $\mathrm{pH}$ $\leq 2$. Botol sampel ditempatkan dalam cool box yang selanjutnya disimpan dalam lemari pendingin sebelum dianalisis di laboratorium. Dan untuk sianida ditambahkan $\mathrm{NaOH}$ hingga $\mathrm{pH} \geq 10$.

\section{Analisis Merkuri Total}

Dalam menganalisis merkuri pada sampel air digunakan metode spektrofotometri serapan atom uap dingin (CVAAS) berdasarkan SNI 6989.78:2011 tentang air dan air limbah - bagian 78 mengenai cara uji raksa $(\mathrm{Hg})$ secara spektrofotometri serapan aton (SSA)-uap dingin atau mercury Analyzer.

\section{Analisis Sianida}

Dalam menganalisis sianida pada sampel air digunakan metode manual sesuai petunjuk penggunaan alat.

Sebelumnya Spektrofotometer HACH DR 5000 dioptimalkan sesuai penggunaan alat. Sampel dimasukkan ke dalam botol sebanyak $10 \mathrm{~mL}$, kemudian ditambahkan satu pillow reagen cyaniver 3 , satu pillow reagen cyaniver 4 , dan satu pillow reagen cyaniver 5 yang kemudian dikocok selama 30 detik lalu didiamkan selama 30 menit. Sampel siap dianalisis pada Spektrofotometer HACH DR 5000 , besarnya konsentrasi sianida dalam sampel dapat langsung dibaca dalam alat tersebut yang sudah dilengkapi dengan system kurva standar yang telah terprogram langsung ke komputer dengan panjang gelombang 612 $\mathrm{nm}$. 


\section{HASIL DAN PEMBAHASAN Merkuri}

Kandungan merkuri yang terdeteksi pada keempat spot menunjukkan hasil yang sama, yaitu dibawah batas limit deteksi $(0,0007 \mathrm{ppm})$. Hal ini dikarenakan para penambang telah beralih dari menggunakan merkuri ke penggunaan sianida dalam proses pengolahan emas. Walaupun demikian, adapula penambang yang masih menggunakan merkuri, yaitu dalam teknik amalgamasi. Teknik ini dilakukan dengan cara mencampurkan batuan yang mengandung emas dan merkuri dalam satu tromol (Kitong et al., 2012). Sesuai pengamatan lapangan, para penambang biasanya menggunakan 4 ons merkuri dalam satu tromol untuk mendapatkan 2 gram emas. Limbah hasil pengolahan tersebut kemudian ditampung ke dalam satu kolam penampungan yang cukup besar. Diduga limbah merkuri ini tidak terdeteksi dalam analisis dikarenakan merkuri telah menguap ke udara dan atau masuk ke dalam tanah sebelum limbah hasil pengolahan tersebut dibuang ke sungai.

Penurunan konsentrasi merkuri di DAS Talawaan dapat terlihat jelas. Berbeda dengan penelitian sebelumnya, konsentrasi merkuri menurut Komalig (2006) berkisar 0,0013-0,0015 ppm. Sedangkan berdasarkan hasil penelitian ini, konsentrasi merkuri yang diperoleh dibawah 0,0007 ppm.

\section{Sianida}

Hasil analisis sianida di DAS Talawaan pada 4 spot di sajikan pada tabel di bawah ini.

Tabel 1. Hasil Analisis Sianida

\begin{tabular}{|l|c|c|c|}
\hline \multirow{2}{*}{ Lokasi } & \multicolumn{2}{|c|}{ Konsentrasi (ppm) } & \multirow{2}{*}{$\begin{array}{c}\text { Rata-rata } \\
\text { (ppm) }\end{array}$} \\
\cline { 2 - 3 } & I & II & 0.004 \\
\hline Desa Wasian (Spot 1) & 0.007 & 0.001 & 0.008 \\
\hline Desa Talawaan (Spot 2) & 0.01 & 0.006 & 0.003 \\
\hline Desa Patokaan (Spot 3) & 0.005 & 0.001 & 0.004 \\
\hline Desa Mianaesa Talawaan Bajo (Spot 4) & 0.005 & 0.003 & \\
\hline
\end{tabular}

Berbeda dengan hasil yang diperoleh pada analisis merkuri, hasil untuk analisis sianida dibeberapa spot pada aliran sungai talawaan adalah berkisar antara 0,001-0,01 ppm. Desa Talawaan yang merupakan spot utama memiliki konsentrasi yang lebih tinggi dibandingkan dengan spot lainnya. Hal ini sesuai dengan hasil yang diharapkan karena sungai yang mengalir di Desa Talawaan dekat dengan tambang emas rakyat.

Pada spot 1 yaitu di Desa Wasian, sampel I menunjukkan hasil yang lebih besar dibandingkan pada spot 3 dan spot 4 . Tingginya konsentrasi ini berasal dari buangan limbah rumah tangga dan dari tumbuh-tumbuhan, karena secara alami sianida dapat ditemukan pada tumbuhtumbuhan dan juga dapat dijumpai pada hasil pembakaran kayu, serta plastik (Abidjulu, 2008; Masloman, 2005). Sesuai pengamatan di lapangan, di sekitar daerah Spot 1 yang merupakan daerah pemukiman tidak ditemukan adanya aktifitas pertambangan yang dapat memberikan kontribusi bahan pencemar.
Pada spot 2 yaitu di Desa Talawaan, sampel I maupun sampel II menunjukan konsentrasi sianida yang lebih besar daripada spot lainnya, yaitu hasil analisis sampel I adalah 0,01 ppm dan pada sampel II adalah $0,006 \mathrm{ppm}$. Hal ini karena kandungan sianida pada air sungai berasal dari aktifitas penambangan emas rakyat yang jarak antara daerah pertambangan dan pengolahan emas dengan spot 2 berdekatan.

Pada spot 3 yaitu di desa Patokaan, kandungan sianida baik pada sampel I maupun sampel II lebih kecil dibandingkan dengan spot 2, yaitu 0,005 ppm dan 0,001 ppm. Sama halnya dengan spot 4 yaitu di desa Minaesa Talawaan Bajo, yaitu 0,005 ppm dan 0,003 ppm. Kandungan sianida ini diduga berasal dari tumbuhan karena secara alamiah sianida dapat ditemukan pada tumbuh-tumbuhan, yaitu terikat pada glukosa (gula) yang disebut amygdalin (Komalig, 2006).

Kandungan sianida pada sampel air dipengaruhi oleh jarak dari tempat pertambangan dan pengolahan emas. Semakin dekat jaraknya, maka semakin besar kandungan sianidanya. Sehingga kandungan 
sianida pada spot II lebih besar dibanding spot lainnya. Selain itu banyaknya kandungan sianida pada hasil analisis juga dipengaruhi oleh faktor cuaca. Analisis pada sampel yang diambil pada saat panas lebih tinggi konsentrasinya dibandingkan dengan pada saat hujan. Hal ini dikarenakan curah hujan dapat mempengaruhi kuat arus sungai serta penambahan volume air dari air hujan.

Berbeda dengan konsentrasi merkuri, konsentrasi sianida tidak berubah secara signifikan. Konsentrasi sianida pada penelitian Komalig (2006), yaitu berkisar 0,005-0,017 ppm, sedangan pada penelitian ini kandungan sianida berkisar 0,001-0,01 ppm.

\section{KESIMPULAN}

- Kandungan merkuri di Daerah Aliran Sungai (DAS) Talawaan tidak terdeteksi pada alat spektrofotometer serapan atom uap dingin (CVAAS) dan kandungan sianida rata-rata berkisar 0,003-0,008 ppm.

- Kandungan merkuri di DAS Talawaan pada tahun 2006 dan Desember 2014 Januari 2015 telah mengalami perubahan, sedangkan sianida tidak mengalami banyak perubahan, yaitu 0,0013-0,0015 ppm menjadi dibawah limit deteksi 0,0007untuk merkuri dan 0,005-0,017 ppm menjadi 0,001-0,01 ppm untuk sianida

\section{SARAN}

Sebaiknya dilakukan penelitian dan pengontrolan secara berkala kandungan sianida dan logam-logam berat yang terakumulasi di DAS Talawaan, baik di air maupun pada sedimen serta pada tanah di sekitar daerah pertambangan.

\section{DAFTAR PUSTAKA}

Abidjulu, J. 2008. Analisis Kualitas Air Sungai Tanoyan Di Kota Kotamobagu Provinsi Sulawesi Utara. Chem. Prog. 1: 105-110.

Inswiarsi, dan H. Martono. 2007. Pencemaran di Wilayah Tambang Emas Rakyat. Media Litbang Kes. 17: 42-50.

Kitong, M. T., J. Abidjulu., H. S. J. Koleangan. 2012. Analisis Merkuri
(Hg) dan Arsen (As) di Sedimen

Sungai Ranoyapo Kecamatan Amurang Sulawesi Utara. J. MIPA UNSRAT Online. 1: 16-19.

Komalig, R. 2006. Analisis Kandungan Merkuri, Arsen dan Sianida di Air Sungai Talawaan dan Kima Bajo [Skripsi]. FMIPA UNSRAT, Manado.

Lestarisa, T. 2010. Faktor-faktor Yang Berhubungan Dengan Keracunan Merkuri (Hg) Pada Penambang Emas Tanpa Ijin (PETI) Di Kecamatan Kurun Kabupaten Gunung Mas, Kalimantan Tengah [Tesis]. Program Pasca Sarjana Universitas Dipenogoro, Semarang.

Masloman, W. 2005. Analisis Kandungan Merkuri, Arsen, dan Sianida di Sungai Talawaan [Skripsi]. FMIPA UNSRAT, Manado.

Palapa T. M. 2012. Rice Husk Ash for Binding Mercury in the Waste of Traditional Gold Mining in North Sulawesi. J. App. Phytotech. In Environmental Sanitation. 1: 139-145.

Polii B. J., dan D. N. Sonya. 2002. Pendugaan Kandungan Merkuri dan Sianida di Daerah Aliran Sungai (DAS) Buyat Minahasa.

Suheryanto, H. P., Loekitowati, dan E. Doyosi. 2013. Kajian Pencemaran Merkuri Total Di Perairan Sungai Rupit Musi Rawas Sumatera Selatan. Prosiding Semirata FMIPA Universitas Lampung; Lampung. Sumirata 2013 FMIPA UNILA. Hlm 385-39. 